OPEN ACCESS

\title{
Bioreduction of iodate in sediment microcosms
}

\author{
Fabiola Guido-Garcia ${ }^{1}$, Gareth T. W. Law ${ }^{2}$, Jonathan R. Lloyd ${ }^{1}$, Paul Lythgoe ${ }^{1}$ and Katherine Morris ${ }^{1}$ ** \\ 1 Research Centre for Radwaste Disposal and Williamson Research Centre for Molecular Environmental Science, \\ The University of Manchester, Williamson Building, Oxford Road, Manchester M13 9PL, UK \\ 2 Centre for Radiochemistry Research, The University of Manchester, School of Chemistry, Oxford Road, Manchester \\ M13 9PL, UK
}

[Received 28 October 2014; Accepted 1 July 2015; Associate Editor: Nicholas Evans]

\section{ABSTRACT}

Iodine-129 is a high-yield fission product formed in nuclear reactors and is a risk-driving radionuclide in both contaminated land and radioactive waste disposal due to its high mobility and long half-life. Here, the bioreduction behaviour of iodate was investigated by tracking iodine speciation and concentration in solution during the development of progressive anoxia in sediment microcosm experiments incubated at neutral $\mathrm{pH}$. Experiments with acetate added as an electron donor showed the expected cascade of terminal electron-accepting processes. Analysis of solution chemistry showed reduction of iodate to iodide during the early stages of metal (Mn(IV) and Fe(III)) reduction, but with no significant retention of iodine species on solids. There was, however, a net release of natural iodine associated with the sediments to solution when robust iron reduction / sulfate reduction had developed. In addition, over 210 days, the controls with no electron donor and the sterile controls showed no Mn(IV) or Fe(III) reduction but displayed modest sorption of iodate to the sediments in the absence of bioreduction. Overall these results show that under oxic conditions iodate may be partially sorbed to sediments over extended periods but that development of mildly reducing conditions leads to the reductive release of iodine to solution as iodide.

KEYWORDS: iodate, iodide, speciation, bioreduction, radioactive iodine.

\section{Introduction}

IODINE-129 is of regulatory concern in radioactive waste disposal due to its long half-life $\left(\mathrm{t} 1 / 215.7 \times 10^{6} \mathrm{y}\right)$, potential for bioaccumulation and its high environmental mobility as the iodide $\left(\mathrm{I}^{-}\right)$species (Fuge and Johnson, 1986). It is a high-yield fission product formed in nuclear reactors and is a significant contaminant at nuclear facilities (Hou et al., 2009; Tykva and Berg, 2004). Iodine-129 is considered to be one of the main dose-contributors during the long-term geological disposal of

* E-mail: katherine.morris@manchester.ac.uk DOI: $10.1180 /$ minmag.2015.079.6.10 radioactive wastes, therefore to understand the eventual fate of the radionuclide it is vital to understand its biogeochemical behaviour in the natural environment (Madic et al., 2002; Aimoz, 2012). Geological disposal, which is the preferred management and disposal route for higher-activity waste in the UK, is founded globally on an engineered deep subsurface facility. Deep geological disposal uses a 'multi-barrier' approach to contain radionuclides over the long timescales neccesary for the bulk of the radionuclides to undergo significant radioactive decay. It is accepted that these barriers will eventually fail and that this could lead potentially to the long-lived fraction of radionuclides migrating to the distant surroundings or 'far field' of the geological disposal facility.
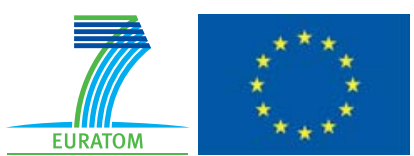

The publication of this research has been funded by the European Union's European Atomic Energy Community's (Euratom) Seventh Framework programme FP7 (2007-2013) under grant agreements $n^{\circ} 249396$, SecIGD, and n`323260, SecIGD2. 
Iodine-129 with its half life of $15.7 \times 10^{6} \mathrm{y}$ and its high mobility in the environment is clearly a radionuclide which may impact on the far field at some point in the future.

Iodine exists naturally as the inorganic species iodate and iodide. Under oxic conditions at circumneutral $\mathrm{pH}$, iodate $\left(\mathrm{IO}_{3}^{-}\right)$dominates and it can be sorbed to mineral phases and sediments (Kodama et al., 2006; Yu et al., 1996). During the development of anoxic conditions, iodate is predicted to be reduced to its lower valence, highly soluble form, iodide $\left(\mathrm{I}^{-}\right)$in the region of $\mathrm{Mn}(\mathrm{IV})$ reducing conditions (Lam and Kuypers, 2011) and has been observed during $\mathrm{Fe}$ (III) reducing conditions (Fox et al., 2010). Depending on the sediment type, partition coefficient $\left(K_{\mathrm{d}}\right)$ values for iodate have been reported to be up to $10^{3} \mathrm{ml} \mathrm{g}^{-1}$ (Schwehr et al., 2009; Fukui et al., 1996; Zhang et al., 2011), whilst $K_{\mathrm{d}}$ values for iodide are routinely below $10 \mathrm{ml} \mathrm{g}^{-1}$ (Kaplan et al., 2000; Zhang et al., 2011) reflecting the lower sorption of iodide species. Iodate is thought to sorb more strongly to sediments containing significant amounts of iron and manganese oxides, and although the mechanism is not fully understood, the formation of an organic $\mathrm{Me}-\mathrm{OIO}_{2}$ bond has been implicated in some studies (Xu et al., 2011). Interestingly, despite the typically small $K_{\mathrm{d}}$ values for iodine interactions with sediments, several studies have explored the interaction of iodide with different minerals including alumina, ferricoxides, mono-sulfate (AFm) phases, pyrite, bacteriogenic iron oxides, birnessite, ferromanganese oxides, kaolinite and illitic minerals (Aimoz et al., 2012; Aimoz et al., 2011; Allard et al., 2009; Couture and Seitz, 1983; Kaplan et al., 2000; Kennedy et al., 2011). Bacteriogenic Fe-oxides and illite showed the highest reactivity for iodide under low-pH conditions whilst pyrite, hematite and kaolinite showed limited, if any, sorption (Aimoz et al., 2011; Kennedy et al., 2011; Kaplan et al., 2000). In a study conducted to test iodide sorption to different iron minerals, only magnetite showed significant levels of sorption (Fuhrmann et al., 1998). In addition, $\mathrm{Mn}$ is implicated in the redox cycling of iodide, with oxidation of iodine to iodate by $\delta \mathrm{MnO}_{2}$ and sorption of iodate to $\delta \mathrm{MnO}_{2}$ also possible (Aimoz et al., 2012; Allard et al., 2009; Fox et al., 2009). Organic matter has also shown significant uptake of iodide, and soil humus is considered to be a considerable sink for iodine in soil systems (Shetaya et al., 2012). Indeed, recent work has highlighted the potential for formation of soluble organo-I compounds (Kaplan, 2003;
Kaplan et al., 2013; Xu et al., 2011) again highlighting the complexity of iodine cycling. Previous studies have suggested that inorganic iodate must first be reduced to transient species such as hypoiodous acid or $\mathrm{I}_{2}$ by organic matter in the soils before it becomes associated with the organic fraction of sediments (Steinberg et al., 2008). By contrast, iodide shows little reaction towards organic matter (Reiller and Moulin, 2002). Iodate sorption to sediments has been shown to be $\mathrm{pH}$ dependent, with sediments at low $\mathrm{pH}$ with a positive charge favouring sorption of anionic $\mathrm{IO}_{3}^{-}$, and ambient to alkaline $\mathrm{pH}$ sediments with neutral / negative charge favouring desorption of anionic $\mathrm{IO}_{3}^{-}$(Yoshida et al., 1992). This is pertinent to iodine behaviour during the attempted remediation of contaminated sites. For example, in a remediation process, limestone was used at the Savannah River facility to promote the precipitation of radionuclides such as $\mathrm{Pu}$ and $\mathrm{U}$ via the generation of alkalinity. The limestone addition caused an increase in $\mathrm{pH}$ from 3.1 to 3.8 in a radionuclide contaminated plume, and although the concentrations of $\mathrm{Pu}$ and $\mathrm{U}$ decreased as intended, iodine-129 desorbed from sediments presumably due to the increase in negatively charged mineral surfaces (Kaplan et al., 2011). In the UK, ${ }^{129}$ I has been detected in groundwater at the Sellafield site, and globally ${ }^{129} \mathrm{I}$ is present in radioactive wastes destined for disposal. It is considered one of the key mobile, long-lived radionuclides present over geological timescales (Stamper et al., 2013).

Even though several studies agree that iodide can be formed under reducing conditions, its behaviour during microbial 'bioreduction' scenarios is not fully understood (Fox et al., 2010; Kaplan et al., 2013; Yamaguchi et al., 2006). Bacterial interactions with iodine have been studied, and show that iodate can be reduced directly by iron- and sulfatereducing bacteria under axenic conditions. Indeed, in one early study, sulfate-reducing species were able to reduce up to $96 \%$ of iodate to iodide in matter of hours (Councell et al., 1997). Marine nitrate reducers such as Pseudomonas, Bacillus, Achromobacter and Vibrio species have been shown to reduce iodate to iodide, and recent work suggests an enzymatic pathway (Lam and Kuypers, 2011). Furthermore, under the effect of a strong oxidizer (birnessite, $\delta \mathrm{MnO}_{2}$ ), iodide was oxidized to elemental iodine and iodate (Allard et al., 2009; Fox et al., 2009) highlighting the likely importance of microbially driven redox cycling processes in predicting iodine speciation and fate in the environment. 
In situ biostimulation through the addition of electron donors to sediments to promote the development of metal-reducing conditions has been proposed as a strategy for managing $\mathrm{Tc}$ and other redox-active radionuclides present as contaminants in groundwater (Lloyd and Renshaw, 2005; Newsome et al., 2014a). Such biostimulation regimes develop reducing conditions, under which the solubility of certain redox-active radionuclides including technetium and uranium is reduced. It is possible, however, that biostimulation aimed at immobilizing $\mathrm{Tc}(\mathrm{VII})$ and $\mathrm{U}(\mathrm{VI})$ may increase the solubility of iodine if it is present in sediments by promoting iodide formation. In addition, microbial processes are now increasingly being recognized as significant during the deep geological disposal of radioactive wastes (Rizoulis et al., 2012; Behrends et al., 2012). Geological disposal facilities (GDF) for higher-activity wastes are yet to be widely implemented, but the generic design includes a series of 'multi-barriers' which are intended to retard migration of radionuclides for as long as possible. However, the engineered barriers will degrade over geological time and long-lived radionuclides will breech the engineered containment and migrate from the repository (Morris et al., 2008). This means understanding iodine- 129 biogeochemistry will be important in both natural and engineered environments.

In this contribution, the redox behaviour of iodate was studied in sediment microcosms under conditions of progressive anoxia, to explore its biocycling behaviour in sediments relevant to radioactively contaminated land, thus providing insight into iodine biocycling in shallow subsurface materials. Reflecting this, the speciation of stable iodine-127 (as iodate) at low concentrations $(9.96 \mu \mathrm{M})$ was tracked during the development of bioreducing conditions in well characterized sediments collected from near the Sellafield nuclear facility. Acetate was used as an electron donor to stimulate microbial redox processes, and the impact of elevated nitrate concentrations on iodine behaviour during bioreduction was also tested.

\section{Methods}

\section{Overview}

A series of sediment microcosms was established using well-characterized materials from near the Sellafield nuclear facility in northwest England. The sediment was used to prepare microcosms with acetate as the electron donor and with varying concentrations of nitrate.

\section{Sample collection}

A well characterized sediment, representative of the Sellafield regional geology (Law et al., 2010a), was collected in sterile containers, sealed and stored at $10^{\circ} \mathrm{C}$ in the dark prior to use.

\section{Microcosm set-up, sampling and analysis}

Sediment microcosms $(10.0 \pm 0.01 \mathrm{~g}$ sediment $)$ were prepared using a range of treatments with a synthetic regional groundwater $(100 \pm 0.10 \mathrm{ml})$ containing $0.3 \mathrm{mM} \mathrm{NaNO}{ }_{3}, 0.4 \mathrm{mM} \mathrm{MgSO}{ }_{4} \cdot 7 \mathrm{H}_{2} \mathrm{O}, 0.09 \mathrm{mM}$ $\mathrm{KCl}, 0.4 \mathrm{mM} \mathrm{MgCl}_{2} \cdot 6 \mathrm{H}_{2} \mathrm{O}, 1.6 \mathrm{mM} \mathrm{CaCO}_{3}, 2.9 \mathrm{mM}$ $\mathrm{NaHCO}_{3}$ and $0.16 \mathrm{mM} \mathrm{NaCl}$ (Wilkins et al., 2007). All experiments were run in triplicate in serum bottles that were crimp sealed with butyl rubber stoppers and similar to past work on e.g. U, Tc and $\mathrm{Np}$ biogeochemistry (Law et al., 2010a; Law et al., 2010b; Newsome et al., 2014b). Microcosm systems were run with the synthetic regional groundwater and: (a) $10 \mathrm{mM}$ acetate (from a Naacetate $\mathrm{pH} 7$ stock); (b) $10 \mathrm{mM}$ acetate $+10 \mathrm{mM}$ nitrate (from a pH $7 \mathrm{NaNO}_{3}$ stock); and (c) no acetate. The synthetic groundwater had sulfate present at $0.4 \mathrm{mM}$ as an electron acceptor. Sterile $\left(20 \mathrm{~min}\right.$ autoclaving at $\left.120^{\circ} \mathrm{C}\right)$ and groundwater only controls were also established. In all systems the groundwater $\mathrm{pH}$ was adjusted to $\sim 7$ prior to the start of the experiment, except for the groundwater only systems where the $\mathrm{pH}$ was $\sim 8$. Finally, the microcosms and controls were spiked to a concentration of $9.96 \mu \mathrm{M}(2 \mathrm{ppm})$ of iodate as sodium iodate. All systems were then incubated anaerobically at room temperature $\left(20 \pm 2^{\circ} \mathrm{C}\right)$ in the dark for 210 days. In addition, to assess abiotic iodate behaviour, pre-reduced sulfate reducing sediments were then autoclaved and reacted with iodate. These microcosms were sampled over one week to assess the rate and extent of any abiotic $\mathrm{IO}_{3}^{-}$reduction.

Sampling was conducted periodically as sediment anoxia developed and sediment slurry was extracted from the microcosms using a sterile syringe and needle, and centrifuged (7000 g) to separate groundwater and sediment. Groundwater samples were analysed for total iodine by inductively coupled plasma mass spectrometry (ICP-MS) (Agilent 7500cx; Brown et al., 2007) and iodine speciation was analysed by chromatographic separation (Hamilton PRP-X100 anion exchange 
column) followed by ICP-MS analysis (Brown et al., 2007; Shetaya et al., 2012). Spectrasol (1\% CFA-C) was used throughout to minimize build-up of iodine species during analysis (Brown et al., 2007). Samples were stored in the dark at $4^{\circ} \mathrm{C}$ for a maximum of 4-5 weeks prior to analysis and a mixed iodate/iodide standard was analysed routinely to provide confidence in measurement stability and storage procedures. Total dissolved $\mathrm{NO}_{2}^{-}, \mathrm{Mn}$ and $\mathrm{Fe}$ concentrations were measured with standard UV-vis spectroscopy methods (Goto et al., 1977; Harris and Mortimer, 2002; Viollier et al., 2000) and aqueous $\mathrm{NO}_{3}^{-}$and $\mathrm{SO}_{4}^{2-}$ were measured by ion chromatography (Dionex AG11$\mathrm{HC}$ ). The total bioavailable $\mathrm{Fe}(\mathrm{III})$ and the proportion of extractable $\mathrm{Fe}(\mathrm{II})$ in the sediment was measured using ferrozine following the method of Lovley and Phillips (1986). The $\mathrm{pH}$ and Eh were measured with a digital meter (Denver Instrument Company) and calibrated electrodes. Standards were used routinely to check the reliability of the methods and calibrations typically had $R^{2} \geq 0.99$. Bulk mineralogy and sediment chemical composition were determined by X-ray fluorescence (Thermo ARL $9400 \mathrm{XRF}$ ) and powder X-ray diffraction (Bruker D8 Advance XRD). Total iodine in the sediment as sampled was determined via extraction with tetramethylammonium hydroxide (TMAH) followed by ICP-MS analysis (Yamada et al., 1996).

\section{Results and discussion}

\section{Sediment characteristics}

The sediment consisted of quartz, sheet silicates (muscovite and chlorite) and minor albite and microcline, which was consistent with past studies (Law et al., 2010a). The total organic carbon content was low $(0.56 \pm 0.08$ wt. $\%)$ and iron oxides were also found in sediment at $5.3 \mathrm{wt} . \%$. The concentration of iodine extracted from the sediment by $5 \%$

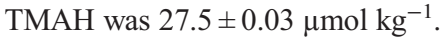

\section{Progressive bioreduction}

No significant biogeochemical changes were noted in sterile microcosms, or systems without added acetate over 210 days (Fig. 1). The $\mathrm{pH}$ in the sterile systems stabilized at $\mathrm{pH} 6.8$ and the $\mathrm{pH}$ in groundwater only controls was constant at $\mathrm{pH} 8.0$ (Fig. 1). The microbially active microcosms which were amended with $10 \mathrm{~mm}$ acetate showed significant
$(>90 \%)$ acetate removal at experimental end points consistent with its use as an electron donor. Bioreduction proceeded at different rates depending on the initial nitrate concentration. In the acetate only systems, low concentrations of nitrate $(0.32 \mathrm{mM})$ were present in groundwater, the $\mathrm{pH}$ was stable at 6.9 , with nitrate reduction starting after two days (Fig. 1a). The systems with acetate and $10 \mathrm{mM}$ nitrate took longer to remove nitrate but complete removal had occurred by day 20 (Fig. 1a). In both systems, transient nitrite was observed in porewaters and in the high-nitrate experiments increasing headspace pressure suggested ingrowth of $\mathrm{N}_{2}$ or $\mathrm{N}_{2} \mathrm{O}$ from denitrification. In the $10 \mathrm{mM}$ nitrate system the $\mathrm{pH}$ also increased from $\mathrm{pH} 7.1$ to $\mathrm{pH} 8.3$ presumably due to alkalinity production during nitrate reduction (Thorpe et al., 2012). In the low nitrate, acetate amended systems, Mn(II) was present in porewater from day 23 , followed by $\mathrm{Fe}(\mathrm{III})$ reduction as indicated by $\mathrm{Fe}$ (II) ingrowth to sediments from day 30 and $\mathrm{Fe}$ in porewaters from day 37. For the acetate with $10 \mathrm{mM}$ nitrate systems, metal reduction was delayed with $\mathrm{Mn}_{(\mathrm{aq})}$ detected by day 44 and $\mathrm{Fe}(\mathrm{II})_{(\mathrm{aq})}$ from day 66 presumably due to excess nitrate in the experiment. Finally, in experiments with acetate only, sulfate reduction was indicated by a decrease in aqueous sulfate from $\sim 90$ days when the $\mathrm{Fe}(\mathrm{II}) / \mathrm{Fe}$ (III) ratio in the solids was $>70 \%$. Similarly, in the acetate with $10 \mathrm{mM}$ nitrate systems, sulfate reduction was observed from $\sim 90$ days when $\mathrm{Fe}(\mathrm{II}) / \mathrm{Fe}$ (III) ratios were $>\sim 70 \%$ with essentially complete reduction in both systems by 210 days (Fig. 1e).

\section{lodine fate during bioreduction}

No changes in iodine speciation were evident in the groundwater-only system, with essentially all of the added iodate remaining in solution throughout the incubation (Fig. 2a). Interestingly, there was evidence for modest sorption of iodine to sterile sediments over the duration of the experiment, with $8.43 \pm 0.38 \mu \mathrm{M}$ total iodine present in solution at day $210\left(15 \%\right.$ removal, $\left.K_{\mathrm{d}}=3.04 \mathrm{ml} \mathrm{g}^{-1}\right)$. This removal from solution was attributed to sorption to sediments although it is clear that in sterile oxic systems, the extent of sorption was limited with $>85 \%$ of the iodine in solution at 210 days. Indeed, iodate was the dominant species in the system at the end of the experiment $(73 \pm 2 \%$ iodate and $10 \pm 3 \%$ iodide; Fig. 2b). In the systems without added acetate, again there was no evidence for iodate reduction, reflecting the fact there were negligible 

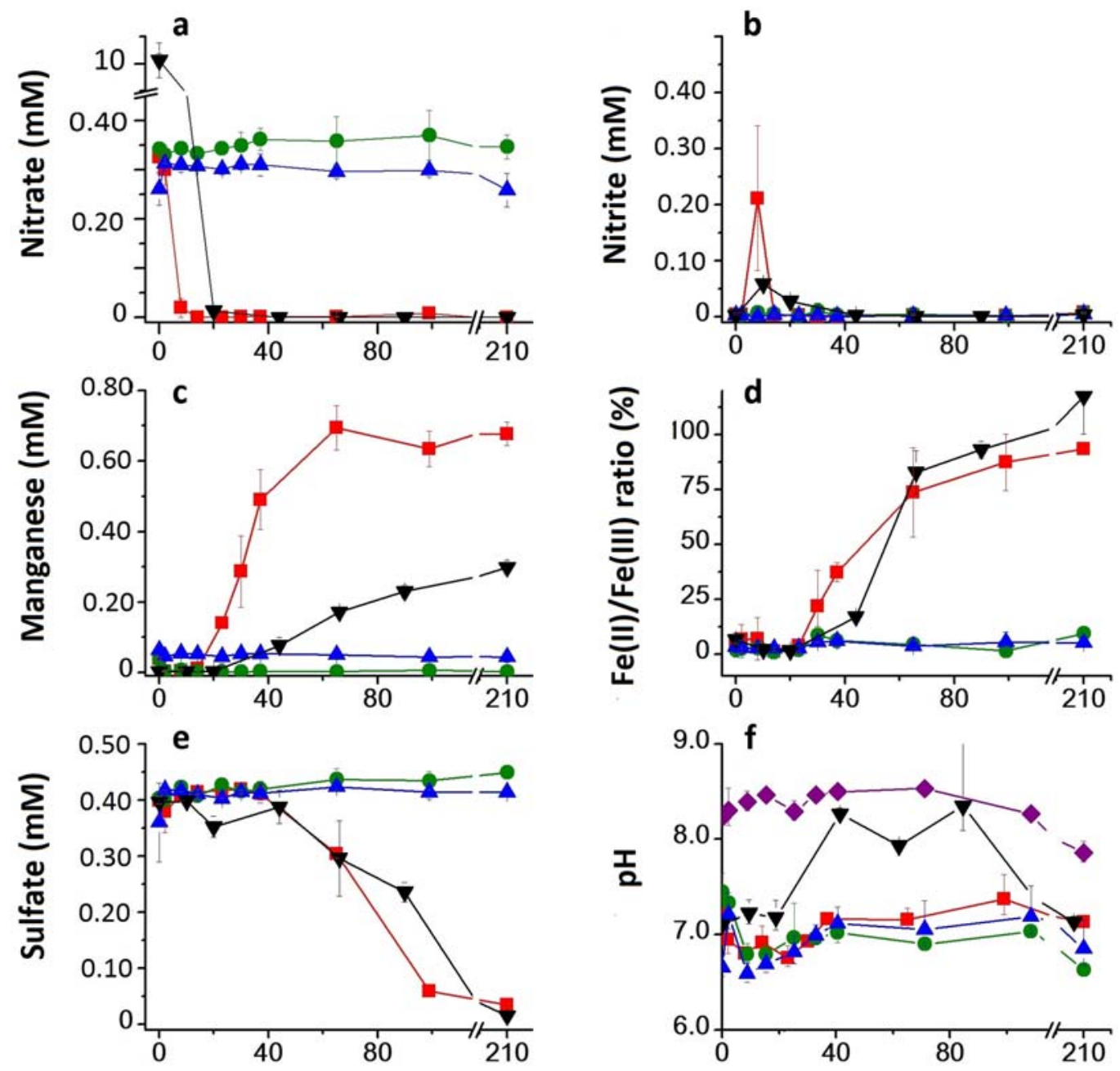

\section{Time point (Days)}

FIG. 1. Sediment microcosm incubation time data (0-250 days). (a) $\mathrm{NO}_{3^{-}} ;(b) \mathrm{NO}_{2^{-}} ;(c) \mathrm{Mn}(\mathrm{aq})$; (d) Percent of $0.5 \mathrm{~N} \mathrm{HCl}$ extractable Fe present as $\mathrm{Fe}(\mathrm{II})$ in sediments; $(e)$ groundwater $\mathrm{SO}_{4}^{2-}$; and $(f)$ groundwater $\mathrm{pH}$. Note: $=$ acetate amended systems, $\boldsymbol{\Theta}=$ no added acetate systems, $\boldsymbol{\Lambda}=$ sterile control systems, $\boldsymbol{\nabla}=$ acetate and $[10 \mathrm{mM}]$ nitrate amended systems, = groundwater only. Error bars are $1 \sigma$ of triplicate microcosm experiments (where not visible, error bars are within the symbol size).

changes in other biogeochemical indicators (Fig. 1) and confirming that natural levels of organic electron donor were very low in these sediments consistent with past work (Law et al., 2010a). Here, total iodine analyses again showed modest levels of sorption of iodate to sediments, similar to the sterile systems. Total iodine data showed $6.16 \pm 1.06 \mu \mathrm{M}$ in solution at 210 days $\left(46 \pm 7 \%\right.$ removal, $K_{\mathrm{d}}=$
$4.61 \mathrm{ml} \mathrm{g}^{-1}$; Fig. 2c). Again, speciation data suggested that iodate dominated the aqueous speciation at 210 days. This longer term and modest sorption of iodate in these experiments is similar to past work (Xu et al., 2011; Shetaya et al., 2012).

In the acetate-only bioreduction experiment, the total iodine remaining in solution showed a modest but significant increase from the added $9.96 \mu \mathrm{M}$ to 


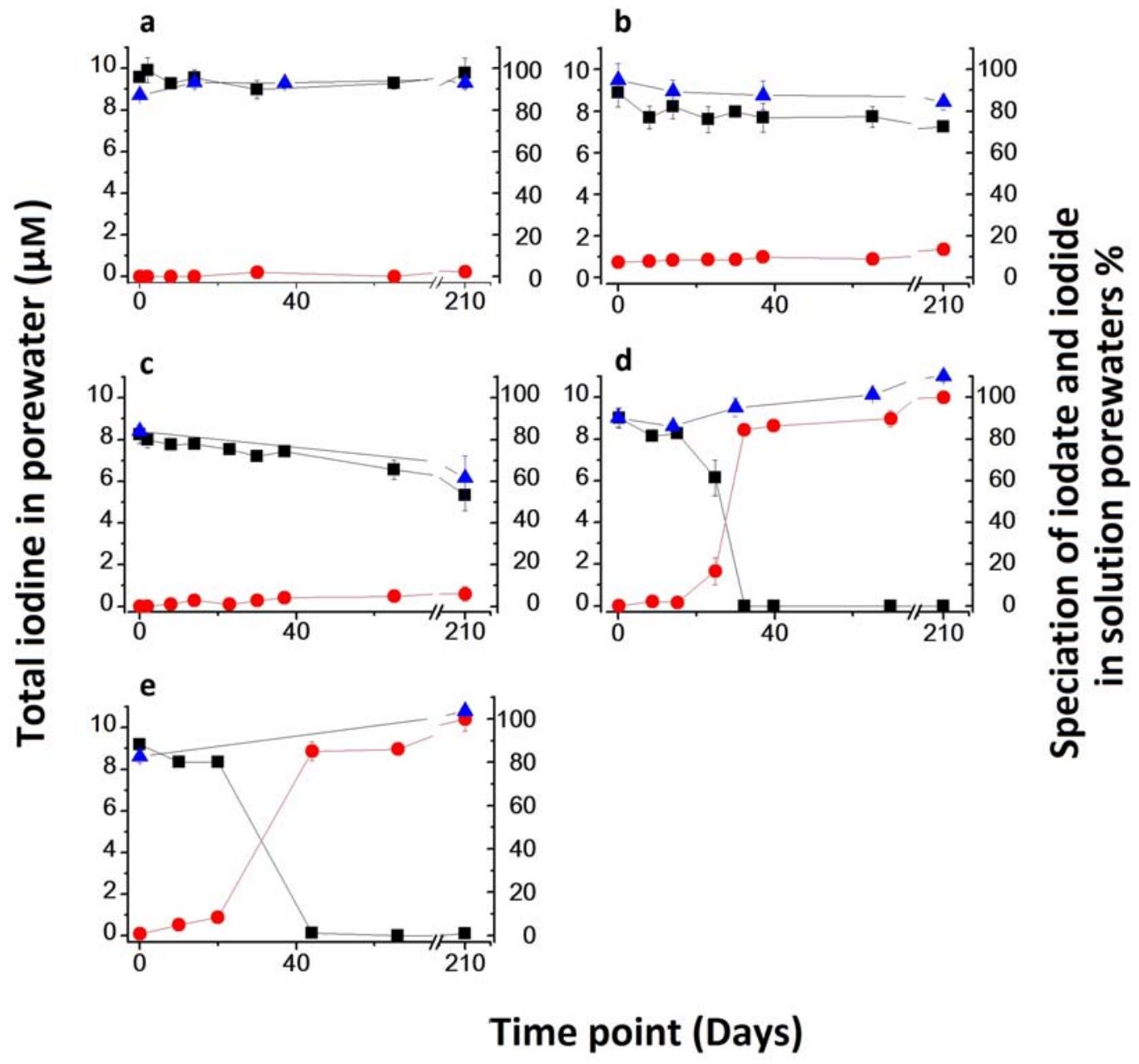

FIG. 2. Iodate reduction-time data ( $0-250$ days) from: ( $a$ ) groundwater only experiments; $(b)$ sterile control; $(c)$ no acetate system; $(d)$ acetate amended system; and $(e)$ acetate and $[10 \mathrm{mM}]$ amended system. $\mathbf{\Delta}=$ total iodine in porewater $(\mu \mathrm{M})$, - $=\mathrm{IO}_{3}^{-}(\%), \mathbf{O}=\% \mathrm{I}^{-}(\%)$. Error bars are $1 \sigma$ experimental uncertainty from triplicate microcosm experiments (where not visible, error bars are within the symbol size).

$11.0 \pm 0.27 \mu \mathrm{M}$ by day 210 where the $\mathrm{Fe}(\mathrm{II}) / \mathrm{Fe}(\mathrm{III})$ ratio was $>70 \%$ and sulfate reduction had developed in the microcosm. The extractable iodine in the sediment was measured using TMAH extractions as $27.5 \mu \mathrm{M} \mathrm{kg}^{-1}$. Mass balance calculations suggest that in microcosms up to $2.8 \mu \mathrm{M}^{-1}$, additional iodine could be supplied by release of this pool of natural iodine bound to sediments. Indeed, in an acetate stimulated control experiment with no added iodate, there was a release of $\sim 2.0 \mu \mathrm{M} \mathrm{l}^{-1}$ iodide to solution over 210 days (data not shown) again highlighting reductive release of the natural pool of iodine in these samples. This reductive release pathway for natural, sediment bound iodine has also been observed in other studies (Fox et al., 2010, Yamaguchi et al., 2006).

The aqueous speciation data for iodine in the acetate-only systems showed that the iodate levels decreased as iodide increased in porewaters. The iodate in solution was removed by day 30 leaving essentially all iodine in solution speciated as iodide (Fig. $2 d$ ). By 30 days Mn reduction was established and the $\mathrm{Fe}(\mathrm{II}) / \mathrm{Fe}$ (III) ratio in sediments was $20 \%$ indicating that early metal-reducing conditions were established at the point of essentially complete iodate reduction to iodide. This is in agreement 
with Lam and Kuypers (2011), who suggest that iodate is theoretically reduced at the same time as manganese reduction. Interestingly, when pre-reduced autoclaved sediments (with 100\% $\mathrm{Fe}(\mathrm{II}))$ were spiked with $9.96 \mu \mathrm{M} \mathrm{IO}_{3}^{-}$, essentially complete reduction of iodate to iodide occurred over 1 week. This confirms that abiotic reduction of iodate is possible in these systems, where both $\mathrm{Fe}(\mathrm{II})$ and sulfide are present and in agreement with past work (Councell et al., 1997).

In the acetate with $10 \mathrm{~mm}$ nitrate systems, iodine followed a similar pattern to the acetate only experiment but the onset of iodate reduction was delayed to 44 days, reflecting the elevated nitrate concentrations in solution; an extended period of nitrate reduction was observed in the microcosms before iodate was reduced (Fig. 2e). Again, total iodine increased to $10.8 \pm 0.2 \mu \mathrm{M}$ during the incubation period and again this suggests that some of the sediment-bound iodine in the system was being released as a consequence of the microbially mediated generation of reducing conditions. Aqueous speciation measurements suggested that in the first 20 days of incubation, iodine speciation was dominated by iodate with significant reduction to iodide occurring by day 44 . At this point, nitrate had been completely removed from porewaters, Mn concentration in porewaters had increased and $\mathrm{Fe}(\mathrm{II}) / \mathrm{Fe}(\mathrm{III})$ ratios in sediments were $17 \pm 1.0 \%$ suggesting that early metalreducing conditions had developed by the point at which iodate was reduced to iodide. Finally, in both $10 \mathrm{mM}$ and acetate-only systems the final concentrations of iodide accounted for all the iodine present in solution and in fact were higher than the original spike. This confirmed that the aqueous species accounted for essentially all of the iodine in the experimental pool.

\section{Conclusions}

The results of this study shows that in sterile and no-electron-donor control experiments, iodate can be sorbed to sediments over several months. In addition, development of early metal-reducing conditions leads to complete reduction of iodate to iodide: all iodide that forms is released into solution. Furthermore, in both microbially active experiments, the total iodine measurements suggested a net release of iodide from sediments during bioreduction. This suggests that an additional source of natural sediment bound iodine was released to solution as iodide under metal- or sulfate-reducing conditions. In many systems, bioreduction has been shown to retard migration of radionuclides such as uranium and technetium (Newsome et al., 2014a), but the enhanced levels of iodine detected in solution under anaerobic conditions, are consistent with bioreduction causing an indirect reductive solubilization of iodine through formation of iodide. When considering the longterm management of radioactive-contaminated land and the disposal of radioactive waste, this study suggests that ${ }^{129} \mathrm{I}$ may be less mobile in oxic environments where the $\mathrm{IO}_{3}^{-}$species will dominate. Further work is needed to define the point in the biogeochemical cascade at which iodate reduction occurs and also its fate on sediment reoxidation with air and nitrate.

\section{Acknowledgements}

This work was supported by the Mexican National Council for Science and Technology (CONACyT) and the UK NERC BIGRAD grant (NE/H007768/1). The authors thank Alastair Bewsher and Nicholas MastersWaage (The University of Manchester) for help with data acquisition.

\section{References}

Aimoz, L., Curti, E. and Mäder, U. (2011) Iodide interaction with natural pyrite. Journal of Radioanalytical and Nuclear Chemistry, 288, 517-524.

Aimoz, L., Wieland, E., Taviot-Guého, C., Dähn, R., Vespa, M. and Churakov, S.V. (2012) Structural insight into iodide uptake by AFm phases. Environmental Science \& Technology, 46, 3874-3881.

Allard, S., von Gunten, U., Sahli, E., Nicolau, R. and Gallard, H. (2009). Oxidation of iodide and iodine on birnessite $\left(\right.$ delta- $\left.\mathrm{MnO}_{2}\right)$ in the $\mathrm{pH}$ range 4-8. Water Research, 43, 3417-3426.

Behrends, T., Krawczyk-Bärsch, E. and Arnold, T. (2012) Implementation of microbial processes in the performance assessment of spent nuclear fuel repositories. Applied Geochemistry, 27, 453-462.

Brown, C.F., Geiszler, K.N. and Lindberg, M.J. (2007) Analysis of ${ }^{129} \mathrm{I}$ in groundwater samples: Direct and quantitative results below the drinking water standard. Applied Geochemistry, 22, 648-655.

Councell, T.B., Landa, E.R. and Lovley, D.R. (1997) Microbial reduction of iodate. Water, Air and Soil Pollution, 100, 99-106.

Couture, R.A. and Seitz, M.G. (1983) Sorption of iodide by $\mathrm{Fe}$ oxides and kaolinite. Nuclear and Chemical Waste Management, 4, 301-306.

Fox, P., Davis, J. and Luther III, G.W. (2009) The kinetics of iodide oxidation by the manganese oxide mineral 
birnessite. Geochimica et Cosmochimica Acta, 73, 2850-2861.

Fox, P.M., Kent, D.B. and Davis, J.A. (2010) Redox transformations and transport of cesium and iodine $(-1,0,+5)$ in oxidizing and reducing zones of a sand and gravel aquifer. Environmental Science \& Technology, 44, 1940-1946.

Fuge, R. and Johnson, C. (1986) The geochemistry of iodine - a review. Environmental Geochemistry and Health, 8, 31-54.

Fuhrmann, M., Bajt, S. and Schoonen, M.A.A. (1998) Sorption of iodine on minerals investigated by X-ray absorption near edge structure (XANES) and ${ }^{125} \mathrm{I}$ tracer sorption experiments. Applied Geochemistry, 13, 127-141.

Fukui, M., Fujikawa, Y. and Satta, N. (1996) Factors affecting interaction of radioiodine and iodate species in soil. Journal of Environmental Radioactivity, 31, 199-216.

Goto, K., Taguchi, S., Fukue, Y. and Ohta, K. (1977) Spectrophotometric determination of manganese with 1-(2-pyridylazo)-2-naphthol and a non-ionic surfactant. Talanta, 24, 752-753.

Harris, S.J. and Mortimer, R.J.G. (2002) Determination of nitrate in small water samples $(100 \mu \mathrm{L})$ by the cadmium-copper reduction method. International Journal of Environmental Analytical Chemistry, 82, 369-376.

Hou, X., Hansen, V., Aldahan, A., Possnert, G., Lind, O. C. and Lujaniene, G. (2009) A review on speciation of iodine-129 in the environmental and biological samples. Analytica Chimica Acta, 632, 181-96.

Kaplan, D.I. (2003) Influence of surface charge of an Feoxide and an organic matter dominated soil on iodide and pertechnetate sorption. Radiochimica Acta, 91, 173-178.

Kaplan, D.I., Serne, R.J., Parker, K.E. and Kutnyakov, I.V. (2000) Iodide sorption to subsurface sediments and illitic minerals. Environmental Science \& Technology, 34, 399-405.

Kaplan, D.I., Roberts, K.A., Schwehr, K.A., Lilley, M.S., Brinkmeyer, R., Denham, DiPrete, D., Li, H.P., Powell, B.A., Xu, C., Yeager, C.M., Zhang, S. and Santschi, P.H. (2011) Evaluation of a radioiodine plume increasing in concentration at the Savannah River Site. Environmental Science \& Technology, 45, 489-95.

Kaplan, D.I., Zhang, S., Roberts, K.A., Schwehr, K., Xu, C., Creeley, D., Ho, Y.F., Li, H.P., Yeager, C.M. and Santschi, P.H. (2013) Radioiodine concentrated in a wetland. Journal of Environmental Radioactivity, 131, 57-61.

Kennedy, C.B., Gault, A.G., Fortin, D., Clark, I.D. and Ferris, F.G. (2011) Retention of iodide by bacteriogenic iron oxides. Geomicrobiology Journal, 28, 387-395.
Kodama, S., Takahashi, Y., Okumura, K. and Uruga, T. (2006) Speciation of iodine in solid environmental samples by iodine K-edge XANES: application to soils and ferromanganese oxides. The Science of the Total Environment, 363, 275-84.

Lam, P. and Kuypers, M.M.M. (2011) Microbial nitrogen cycling processes in oxygen minimum zones. Annual Review of Marine Science, 3, 317-45.

Law, G.T.W., Geissler, A., Boothman, C., Burke, I.T., Livens, F.R., Lloyd, J.R. and Morris, K. (2010a) Role of nitrate in conditioning aquifer sediments for technetium bioreduction. Environmental Science \& Technology, 44, 150-155.

Law, G.T.W., Geissler, A., Lloyd, J.R., Livens, F.R., Boothman, C., Begg, J.D.C., Denecke, M., Rothe, J., Dardenne, K., Burke, I.T.,Charnock, J.M., Morris, K. (2010b) Geomicrobiological redox cycling of the transeuranic element neptunium. Environmental Science \& Technology, 44, 8924-8929.

Lloyd, J.R. and Renshaw, J.C. (2005) Bioremediation of radioactive waste: radionuclide-microbe interactions in laboratory and field-scale studies. Current Opinion in Biotechnology, 16, 254-260.

Lovley, D.R. and Phillips, E.J.P. (1986) Organic matter mineralization with reduction of ferric iron in anaerobic sediments. Applied and Environmental Microbiology, 51, 683-689.

Madic, C., Baron, P. and Boullis, B. (2002) Separation of long-lived radionuclides from high active nuclear waste. Comptes Rendus Physique, 3, 797-811.

Morris. K., Law, G.T.W., Bryan, N.D. (2008) Chapter 3. Geodisposal of higher activity wastes. pp. 129-151 in: Nuclear Power and the Environment. Issues in Environmental Science and Technology, v32 (R.E. Hester and R.M. Harrison, editors). Royal Society of Chemistry, London.

Nagata, T., Fukushi, K. and Takahashi, Y. (2009) Prediction of iodide adsorption on oxides by surface complexation modeling with spectroscopic confirmation. Journal of Colloid and Interface Science, 332, 309-16.

Newsome, L., Morris, K. and Lloyd, J.R. (2014a) The biogeochemistry and bioremediation of uranium and other priority radionuclides. Chemical Geology, 363, 164-184.

Newsome, L., Morris, K., Trivedi, D., Atherton, N. and Lloyd, J.R. (2014b) Microbial reduction of uranium (VI) in sediments of different lithologies collected from Sellafield. Applied Geochemistry, 51, 55-64.

Reiller, P. and Moulin, V. (2002) Influence of organic matter in the prediction of iodine migration in natural environment. Scientific Basis for Nuclear Waste Management XXVI, 565-570.

Rizoulis, A., Steele, H.M., Morris, K. and Lloyd, J.R. (2012) The potential impact of anaerobic microbial metabolism during the geological disposal of 
intermediate-level waste. Mineralogical Magazine, 76, 3261-3270.

Schwehr, K.A., Santschi, P.H., Kaplan, D.J., Yeager, C.M. and Brinkmeyer, R. (2009) Organo-iodine formation in soils and aquifer sediments at ambient concentrations. Environmental Science \& Technology, 43, 7258-7264.

Shetaya, W.H., Young, S.D., Watts, M.J., Ander, E.L. and Bailey, E.H. (2012) Iodine dynamics in soils. Geochimica et Cosmochimica Acta, 77, 457-473.

Stamper, A., McKinlay, C., Coughlin, D. and Laws, F. (2013) Groundwater Monitoring at Sellafield: Annual Data Review 2012. Nuclear Decommisioning Authority, Seascale, Cumbria, UK.

Steinberg, S.M., Kimble, G.M., Schmett, G.T., Emerson, D.W., Turner, M.F. and Rudin, M. (2008) Abiotic reaction of iodate with sphagnum peat and other natural organic matter. Journal of Radioanalytical and Nuclear Chemistry, 277, 185-191.

Thorpe, C.L., Lloyd, J.R., Law, G.T.W., Burke, I.T., Shaw, S., Bryan, N.D. and Morris, K. (2012) Strontium sorption and precipitation behaviour during bioreduction in nitrate impacted sediments. Chemical Geology, 306, 114-122.

Tykva, R. and Berg, D. (editors) (2004) Man-Made and Natural Radioactivity in Environmental Pollution and Radiochronology. Springer Science and Business Media, Berlin, Heidelberg, 416 pp.

Viollier, E., Inglett, P.W., Hunter, K., Roychoudhury, A.N . and Van Cappellen, P. (2000) The ferrozine method revisited: $\mathrm{Fe}(\mathrm{II}) / \mathrm{Fe}(\mathrm{III})$ determination in natural waters. Applied Geochemistry, 15, 785-790.

Wilkins, M.J., Livens, F.R., Vaughan, D.J., Beadle, I. and Lloyd, J.R. (2007) The influence of microbial redox cycling on radionuclide mobility in the subsurface at a low-level radioactive waste storage site. Geobiology, $\mathbf{5}$, 293-301.

Xu, C., Zhang, S., Ho, Y.-F., Miller, E.J., Roberts, K., Li, H.-P., Schwehr, K.A., Otosaka, S., Kaplan, D.I., Brinkmeyer, R., Yeager, C.M. and Santschi, P.H. (2011) Is soil natural organic matter a sink or source for mobile radioiodine $\left({ }^{129} \mathrm{I}\right)$ at the Savannah River Site? Geochimica et Cosmochimica Acta, 75, 5716-5735.

Yamada, H., Kiriyama, T. and Yonebayashi, K. (1996) Determination of total iodine in soils by Inductively Coupled Plasma Mass Spectrometry. Soil Science and Plant Nutrition, 42, 859-866.

Yamaguchi, N., Nakano, M., Tanida, H., Fujiwara, H. and Kihou, N. (2006) Redox reaction of iodine in paddy soil investigated by field observation and the I K-Edge XANES fingerprinting method. Journal of Environmental Radioactivity, 86, 212-226.

Yoshida, S., Muramatsu, Y. and Uchida, S. (1992) Studies on the sorption of $\mathrm{I}^{-}$(iodide) and $\mathrm{IO}_{3}^{-}$(iodate) onto andosols. Water, Air, and Soil Pollution Soil Pollution, 63, 321-329.

Yu, Z., Warner, J.A., Dahlgren, R. and Casey, W.H. (1996) Reactivity of iodide in volcanic soils and noncrystalline soil constituents. Geochimica et Cosmochimica acta, 60, 4945-4956.

Zhang, S., Du, J., Xu, C., Schwehr, K.A., Ho, Y.-F., Li, H.P., Roberts, K.A., Kaplan, D.I., Brinkmeyer, R., Yeager, C.M., Chang, H-S. and Santschi, P.H. (2011) Concentration-dependent mobility, retardation, and speciation of iodine in surface sediment from the Savannah River Site. Environmental Science \& Technology, 45, 5543-5549. 